\title{
Forming university students healthy lifestyle through the mastering the discipline "Pedagogy"
}

\author{
E.A. Akimova ${ }^{1 *}$, N.V. Levchenko ${ }^{2}$, and T.A. Maslova ${ }^{3}$ \\ ${ }^{1}$ Kaluga State University named after K.E. Tsiolkovsky, Kaluga, Russia \\ ${ }^{2}$ Kaluga State University named after K.E. Tsiolkovsky, Kaluga, Russia \\ ${ }^{3}$ Kaluga State University named after K.E. Tsiolkovsky, Kaluga, Russia
}

\begin{abstract}
The article deals with the problem of students (future teachers) health. To solve the problem of preserving and strengthening the health of university students, the authors propose a group of methods for the formation of healthy lifestyle (HLS) culture through the mastering the educational discipline of the pedagogical cycle. In the formation of a student's healthy lifestyle culture the main components are distinguished: cognitive-semantic, emotional-volitional, reflexive-evaluative. The assessment of the levels of healthy lifestyle formation among university students is proposed. Within the framework of the discipline "Pedagogy" in its first module "Introduction to the teaching profession" a developed program "Health as a value" was proposed to second-year students of the Kaluga State University named after K.E. Tsiolkovsky. This program was implemented in the experimental group.
\end{abstract}

\section{A problem statement}

At the present stage of education development, significant and complex processes of renewal and modernization are taking place. Along with the huge achievements associated, first of all, with the freedom of choice of elective courses, teaching technologies, teaching methods, the emergence of innovative, alternative educational institutions, little attention is paid to the formation of student's healthy lifestyle in the educational process. Health - one of the basic concepts of medicine and human ecology, the main indicator of human life quality. This is a hot topic of discussion at all times. The solution to the problem of preserving and strengthening the health of students requires new approaches, first of all, in the formation of student's healthy lifestyle.

Dissertation research in recent years, speaks about the relevance of this topic for scientific research. So, K.V. Plankin points to the need to form a safety culture of student youth in the process of cultural and leisure activities [1], also in 2017, N.A. Zinoviev considers in his pedagogical research the issue of forming a healthy lifestyle among students of a technical university in the process of physical education [2], and in 2019 S.A.

*Corresponding author: ipcs-profped@yandex.ru 
Alesirej reveals the technology of forming a healthy lifestyle for bachelor students in the educational environment of the higher school in the Republic of Iraq [3]. The technologies that make it possible to forecast opportunities for studying without prejudice to physical and mental health, to organize a health-preserving educational process today are clearly not enough.

This contradiction between the presence of a significant number of pedagogical methods to preserve the health of students in the educational process and the lack of effectively developed programs for the formation of a healthy lifestyle in a student served as the basis for our research.

The relevance of the study is also due to the fact that today there is an acute problem of creating a scientifically grounded methodology for the formation of a culture of a healthy lifestyle among university students through the development of academic disciplines of the pedagogical cycle.

\subsection{The objective of the work}

Scientists E.N. Markov, N.I. Novoselova, N.A. Trigub and others in their works represent an understanding of the essence of healthy lifestyle culture. A healthy lifestyle is viewed as a human need, a system of stable attitudes, which is expressed in everyday behavior, as well as in achieving goals, solving various problems that have developed in the life process, including problems of longevity and health [4].

If we pay attention to the "Concept of the Federal Target Program" Development of Physical Culture and Sports in the Russian Federation for 2016-2020"', the national project "Health" implemented by the Government of the Russian Federation, which are aimed at preserving and strengthening the health of the population, then a number of tasks can be noted, in particular: carrying out preventive measures aimed at changing attitudes towards a healthy lifestyle and the formation of skills and culture and lifestyle, as well as the development and organization of educational programs of educational disciplines aimed at strengthening the health of students and motivating them to maintain and maintain their own health and health surrounding people $[5,6]$.

At the present stage, the inclusion of the education system in solving the problems of strengthening and maintaining the health of students is especially urgent. A large number of psychological and pedagogical methods and technologies developed by both domestic and foreign pedagogy make it possible to determine the student's ability to learn, master the educational material. The factors that directly affect health include a person's lifestyle.

In recent studies, N.P. Abaskalova, R.I. Aizman, M.V. Antropova, V.F. Bazarny, M.M. Bezrukikh, E.N. Weiner, L.I. Lubysheva and others consider aspects related to the safety and healthy lifestyle of university students $[7,8,9,10,11,12,13]$.

Today, socially significant health-preserving technologies are actively used in the educational process, however, the problem of forming a culture of a healthy lifestyle, in particular when studying the disciplines of the pedagogical cycle, is not sufficiently developed.

\section{Materials and the results of the research}

The purpose of the study is to check the effectiveness of the methodology for the formation of a culture of healthy lifestyle for future teachers by mastering the disciplines of the pedagogical cycle in the process of classroom and extracurricular activities.

The objectives of this study were to study modern research on this issue, theoretical substantiation and concretization of the features of the formation of a culture of a healthy 
lifestyle in the educational space of a university, as well as the development and substantiation of criteria for assessing the level of formation of a culture of a healthy lifestyle by studying the disciplines of the pedagogical cycle, on the example of the discipline "Pedagogy", and development, testing of the effectiveness of the presented methodology in practice.

The scientific novelty of the research lies in the fact that this technique can be used in the process of classroom and extracurricular work in order to form a healthy lifestyle for students.

The concept of "healthy lifestyle" is based on the ways of human behavior, his life, the absence of bad habits, maintaining his own health and the health of others, as well as the need to take into account heredity and functional abilities of the body and the person's lifestyle [14]. Knowledge about the current physical condition of one's body is an integral part of the students' healthy lifestyle culture. Without the formation of physical culture, the formation of a culture of a healthy lifestyle is impossible. The culture of a healthy lifestyle has the following components: types and factors of health, as well as the attitude of the individual to himself [15]. It is important to combine the somatic mental physical, as well as the moral health of each person. All these components make up the health of the student, the future teacher.

The content of the disciplines of the pedagogical cycle is based on the educational and developmental potential that effectively allows the teacher to implement the culture of a healthy lifestyle [16].

In the formation of healthy lifestyle culture of students, the main components are distinguished:

- cognitive-semantic (reflection in the mind of the result of mastering knowledge about a healthy lifestyle as a value, awareness of its importance at the personal-semantic level);

- Emotional-strong-willed (represents the quality of attitudes towards activities aimed at implementing a healthy lifestyle);

- reflexive-evaluative (self-esteem, as well as understanding, evaluation and interpretation of the activities of other people, which make it possible to realize how important a healthy lifestyle is for a person).

These components are closely related. Moreover, this relationship is not summary, but systemic, since the value orientation towards a healthy lifestyle is a holistic education in which subjective and personal components are inextricably linked, expressing the internal plan of students' attitude to this value and objective and practical actions.

The main indicators of the level of formation of a healthy lifestyle culture are:

- availability of knowledge about a healthy lifestyle, healthy lifestyle culture;

- awareness of the need to maintain a healthy lifestyle;

- value attitude to health;

- motivation to form a culture of a healthy lifestyle;

- active participation in the formation of a healthy lifestyle culture [17].

In the course of the formative stage of the experiment, we implemented a methodology for the formation of a healthy lifestyle among university students.

We have developed a program "Health as a value", which was implemented in the experimental group.

The program presents the subjects of the university educational process: students, teachers. This research was carried out during one academic semester during the study of the first module "Introduction to the teaching profession" of the discipline "Pedagogy".

This program is focused on strengthening and preserving the health of students as a universal value, the formation of knowledge on health promotion, maintaining a healthy lifestyle and the need for it while mastering the discipline "Pedagogy". 
The ascertaining stage of the experiment consisted in conducting a questionnaire survey using two methods, which showed that a significant part of the students in the experimental group have an initial low level of formation of a healthy lifestyle. The formative stage of the experiment was devoted to the direct implementation of the "Health as a Value" program by means of classroom activity; group work was enhanced by active teaching methods (Table 1).

Table 1. Thematic plan of the program "Health as a value", module 1. Introduction to the teaching profession. General foundations of pedagogy.

\begin{tabular}{|l|l|l|}
\hline $\begin{array}{c}\text { № } \\
\text { p/p }\end{array}$ & \multicolumn{1}{|c|}{ Lesson topic } & \multicolumn{1}{|c|}{ Teaching methods } \\
\hline 1. & $\begin{array}{l}\text { Value characteristics, conditions, means } \\
\text { of implementation of pedagogical activity } \\
\text { by a teacher. }\end{array}$ & $\begin{array}{l}\text { Practical lesson. Interactive conversation, } \\
\text { "brainstorming", discussion of reports. }\end{array}$ \\
\hline 2. & $\begin{array}{l}\text { Development of ideas about the ideal of a } \\
\text { person, goals, values and ways of his } \\
\text { education: stages of history. }\end{array}$ & Problem-lecture, lecture-discussion. \\
\hline 3. & Inclusive education. & $\begin{array}{l}\text { Lecture-conversation, lecture with analysis of } \\
\text { specific situations. }\end{array}$ \\
\hline 4. & Teaching profession in modern society. & $\begin{array}{l}\text { Individual lesson "Types of bad habits in the } \\
\text { student environment and their dangers", a } \\
\text { seminar in the form of a round table. }\end{array}$ \\
\hline 5. & $\begin{array}{l}\text { Modern socio-pedagogical problems of } \\
\text { teaching. }\end{array}$ & $\begin{array}{l}\text { Lecture-conversation on the topic "Coping } \\
\text { with stress". "Self-regulation of the psycho- } \\
\text { emotional state". }\end{array}$ \\
\hline 6. & $\begin{array}{l}\text { Professionally significant qualities of a } \\
\text { teacher's personality, ways of their } \\
\text { development and improvement. }\end{array}$ & $\begin{array}{l}\text { Practical lesson. Role-playing game "Learn to } \\
\text { plan your day". }\end{array}$ \\
\hline 7. & $\begin{array}{l}\text { Factors of socialization and personality } \\
\text { formation. }\end{array}$ & $\begin{array}{l}\text { Practical lesson. Organization of a scientific } \\
\text { mini-conference on healthy lifestyles (healthy } \\
\text { lifestyle). }\end{array}$ \\
\hline
\end{tabular}

The content of the program includes an interactive conversation "What is health as a value?" The following issues are put forward for discussion:

- What, in your opinion, is the foundation of health?

- What, in your opinion, makes up the walls of health?

- What factors affect the student's health?

- Who is responsible for a healthy lifestyle?

- In what place can the health factor be placed in terms of its value?

- List the basic principles of a healthy lifestyle.

- How long should sleep take during the day? The influence of environmental factors on performance?

- Physical activity as a form of recreation. How does the change in the type of activity (mental to physical) affect?

- Inclusive education (creating optimal conditions for socialization for children with disabilities and disabled).

At the end of the lesson, students were asked questions to prepare for the seminar "The teaching profession in modern society." Questions for preparation included such as:

- Types of bad habits in the student environment and their danger.

- The influence of bad habits on the student's body (tobacco smoking, alcohol consumption, drug addiction).

- Measures to prevent bad habits. 
- Monitoring habits (watching TV, playing computer games, surfing the Internet or contacts on social networks).

The next lecture lesson "Modern socio-pedagogical problems of teacher's work" included such questions as: self-regulation of the psychoemotional state, how to cope with stressful situations.

Questions raised at the lecture in the framework of the problem of forming a healthy lifestyle: the concept of stress, the classification of stress and its psychological causes, stress in the student environment, methods of optimizing the mental state.

The program also provided for a role-playing game on the topic "Learn to plan your day." Students were asked to make a calendar planning for the coming week. "For each day, draw up a schedule in accordance with the principles of healthy lifestyle, fill out a "Health" diary (set aside time for training sessions, organize rest, plan meals, physical activity, plan a sleep schedule, give up bad habits, try methods of stress relief)" (Table 2).

Table 2. "Health Diary".

\begin{tabular}{|l|l|l|l|l|l|}
\hline Day & Diet & $\begin{array}{l}\text { Mode of training } \\
\text { sessions }\end{array}$ & Sleep mode & $\begin{array}{l}\text { Physical } \\
\text { activity }\end{array}$ & $\begin{array}{l}\text { Leisure } \\
\text { activities }\end{array}$ \\
\hline 1. & & & & & \\
\hline 2. & & & & & \\
\hline$\ldots$ & & & & & \\
\hline
\end{tabular}

At the end, a final mini-conference was held on the topic "Healthy lifestyle of a student" within the framework of the topic: "Factors of socialization and personality formation." The following questions were sorted out: the mode of physical activity for the mental worker, methods of preventing visual impairment, hardening the body as a means of improving health, drinking regimen, water, tea, coffee, depression in adolescence, influenza, acute respiratory infections - means of prevention and treatment, identification of the main factors that negatively affect the health of student youth in the learning process.

At the end of the experimental work with students, the control stage of the experiment was carried out. At this stage, students were also offered a questionnaire "Attitude of students of KSU named after K.E. Tsiolkovsky to your health "and" The level of knowledge of students of KSU named after K.E. Tsiolkovsky about a healthy lifestyle", which were carried out during the initial experiment.

The main goal of this stage is to determine the level of students' awareness of the requirements of a healthy lifestyle after the experiment (Table 3 ).

The results of the questionnaire showed that: five students reconsidered their attitude and began to attend classes less often with signs of acute viral diseases, now this figure is $43 \%$ (compared to the ascertaining stage of the experiment), decreased by $10 \%$.

The overall percentage of students who do not experience stress has dropped by $15 \%$ to $49 \%$. This indicates that the students have learned how to deal with stress.

To the question "How many hours a day do you sleep on average?" the following results were obtained: the majority of students (49\%) adhere to the correct sleep regimen, which is $21 \%$ more than before the formative stage of the experiment.

It was necessary to determine whether it is interesting for students to continue learning about how to lead a healthy lifestyle. The majority $(83 \%)$ of students are interested in continuing to receive information about the correct conduct of a healthy lifestyle, what to do in order to be less sick, how to eat right and how to reduce stress levels. In comparison with the ascertaining stage of the experiment, this indicator increased by $17 \%$. 
Table 3. Results of the first questionnaire "Students' attitude to their health".

\begin{tabular}{|l|l|l|l|}
\hline $\begin{array}{l}\text { 1. "Do you attend an } \\
\text { educational institution } \\
\text { when you have signs of } \\
\text { an acute viral illness (or } \\
\text { other acute illness)?" }\end{array}$ & Yes, often & Yes, rarely & No \\
\hline $\begin{array}{l}\text { 2. "How often do you } \\
\text { feel stressed, nervous, } \\
\text { worried?" }\end{array}$ & $7(15 \%)$ & $13(28 \%)$ & $27(57 \%)$ \\
\hline $\begin{array}{l}3 . \text { "How many hours a } \\
\text { day do you sleep on } \\
\text { average?" }\end{array}$ & Less than 7 hours & $7-9$ hours & I don't feel \\
\hline $\begin{array}{l}\text { 4. "Are you interested in } \\
\text { continuing to learn how } \\
\text { to lead a healthy } \\
\text { lifestyle?" }\end{array}$ & $\begin{array}{l}\text { Yes, useful } \\
\text { interting }\end{array}$ & $\begin{array}{l}\text { Not } \\
\text { interesting }\end{array}$ & More than 9 hours \\
\hline & $13(28 \%)$ & Not interesting \\
\hline $\begin{array}{l}\text { 5. "Can we say that you } \\
\text { care about your health?" }\end{array}$ & Yes, of course & I care & $23(49 \%)$ \\
\hline & $32(68 \%)$ & $11(23 \%)$ & $4(9 \%)$ \\
\hline $\begin{array}{l}\text { 6. "Compliance with the } \\
\text { daily routine of students } \\
\text { with the requirements of } \\
\text { a healthy lifestyle" }\end{array}$ & Full compliance & $\begin{array}{l}\text { Incomplete } \\
\text { compliance }\end{array}$ & Non-compliance \\
\hline & $19(40 \%)$ & $17(36 \%)$ & $11(23 \%)$ \\
\hline
\end{tabular}

Results of answers to the question "Can we say that you care about your health?" showed that:

$68 \%$ of students have an adequate assessment of their lifestyle.

$23 \%$ of students have an insufficiently adequate grade.

$9 \%$ of students have an inadequate grade.

From the indicators obtained after the survey, we can see that students began to more adequately assess their lifestyle. Because they delved into the topic of healthy lifestyle, learned the main components of a healthy lifestyle, and were able to evaluate yourself from the outside.

The last diagnosed indicator in this questionnaire is the compliance of the students' daily routine with the requirements of a healthy lifestyle.

According to the results of the survey, the following results were obtained: full compliance of the daily routine of students with the requirements of healthy lifestyle - 19 people (46\%); incomplete compliance - 16 people (34\%); inconsistency - 9 people (19\%).

After the formative stage of the experiment, students were offered a "Health Diary", in which they wrote down their daily routine, trying to adhere to a healthy lifestyle. They have developed a habit of adhering to the norms of a healthy lifestyle, as evidenced by the results of the survey. The percentage of students who have "full compliance" with the daily routine of healthy lifestyle requirements increased by $22 \%$ (Table 4 ). 
Table 4. The results of the questionnaire that determine the level of formation of a healthy lifestyle in a student.

\begin{tabular}{|l|l|l|l|}
\hline $\begin{array}{l}\text { "The level of students' knowledge about the influence } \\
\text { of bad habits" }\end{array}$ & High & Medium & Low \\
\hline $\begin{array}{l}\text { "The level of student knowledge about the correct } \\
\text { organization of the daily routine." }\end{array}$ & $41(87 \%)$ & $6(13 \%)$ & $0(0 \%)$ \\
\hline & $44(94 \%)$ & $3(6 \%)$ & $0(0 \%)$ \\
\hline $\begin{array}{l}\text { "The level of knowledge of students about stress, and } \\
\text { methods of dealing with it." }\end{array}$ & High & Medium & Low \\
\hline & $37(79 \%)$ & $8(17 \%)$ & $2(4 \%)$ \\
\hline $\begin{array}{l}\text { "The level of knowledge of the student about the rules } \\
\text { for organizing recreation." }\end{array}$ & High & Medium & Low \\
\hline & $45(96 \%)$ & $2(4 \%)$ & $0(0 \%)$ \\
\hline
\end{tabular}

The received ideas about a healthy lifestyle among university students, after studying the first module of the discipline "Pedagogy", indicate that the knowledge of the surveyed students about the negative impact of bad habits on health is at a sufficient level. $87 \%$ of students showed a high degree of knowledge.

According to the awareness of the rules for organizing the diet, a high level was found among the majority of students $(94 \%)$.

$79 \%$ of students showed a high level of knowledge of students about stress and methods of dealing with it, the average level was found in $17 \%$. This is justified by the fact that stress is a complex emotional state caused by overstrain of the body, and it takes more hours to study it, and a more in-depth study of the material.

Awareness of students about the rules for organizing recreation showed that $96 \%$ of students have a high level.

\section{Conclusions}

The results of the study can also be explained by the fact that in the control group, in contrast to the experimental, in the group form of work, the pedagogical process was organized through the implementation of lectures, in particular: lectures-visualization, problem-lecture, lectures-discussions, as well as lectures-press conferences and lecturestalks, lectures with analysis of specific situations, multimedia lectures and in the form of practical exercises in the form of "brainstorming", round tables, business games, quizzes, detailed conversations, discussion of reports, abstracts, exercises for independent thinking, written works. While for the students of the control group, the classical form of organizing classes was used: presentation, story, frontal survey. These classes were implemented in classroom and extracurricular activities and allowed, within the framework of teaching the discipline "Pedagogy", to form a culture of a healthy lifestyle for future teachers. Evaluation of the effectiveness of the developed program showed that its implementation in the educational process will be more effective within the framework of teaching university students.

It is fair to say that within the framework of the study and the writing of this article, there is no opportunity to consider all the problems we had to face in practice systematically. In the future, we plan to provide an analysis of overcoming emerging problems in the process of implementing the program for the formation of a healthy lifestyle for students in the organization of training in 1 module "Introduction to the teaching profession" of the discipline "Pedagogy". 


\section{References}

1. K.V. Plankin, Formation of a culture of safety of student youth in the process of cultural and leisure activities: dis. ... Cand. ped. Sciences, 169 (Kazan State Institute of Culture, Kazan, 2017)

2. N.A Zinoviev, Formation of a healthy lifestyle among students of a technical university in the process of physical education: dis. ... Cand. ped. Sciences, 213 (St. Petersburg, 2017)

3. S.A. Alezirej, Technology of formation of a healthy lifestyle of bachelor students in the educational environment of higher education in the Republic of Iraq: dis. ... Cand. ped. Sciences, 176 (Maykop, 2019)

4. L.P. Okulova, Methods of forming a culture of a healthy lifestyle among university students through mastering the discipline "Life Safety", Teacher of the XXI century, 1 (2018)

5. Decree of the Government of the Russian Federation of January 21, $2015 \mathrm{~N} 30$ (as revised on June 18, 2019) "On the federal target program" Development of physical culture and sports in the Russian Federation for 2016-2020" (2015)

6. National project "Health" [Electronic resource], Access mode: URL http: // futurerussia.gov.ru/zdravoohranenie (date of treatment 09/16/2020)

7. N.P. Abaskalova, Formation of the foundations of the culture of a healthy and safe lifestyle of students - a component of personality socialization, Formation of a healthy lifestyle for children and adolescents: traditions and innovations, 2, 10-14 (2017)

8. R.I. Aizman, Health of participants in the educational process as a criterion the effectiveness of health-preserving activities in the education system, Domestic and foreign pedagogy, 5 (26), 72-82 (2015)

9. M.V. Antropova, G.G. Manke, G.V. Borodkina, Risk factors and health status of students, Healthcare of the Russian Federation, 3, 53 (2016)

10. V.F. Bazaar, Child of man. Psychophysiology of development and regression, 296 (Moscow, 2009)

11. M.M. Bezrukikh, Psychophysiology of a Child: Textbook, 144 (Voronezh: Publishing House NPO "MODEK", 2005)

12. E.N. Weiner, Remedial physical culture: textbook, 424 (Moscow: FLINT, 2018)

13. L.I. Lubysheva, Actualization of control technologies in physical education and sports personnel training system, TaPPC, 11, 95 (2019)

14. O.E. Andryushchenko, Axiological aspects of the formation of a healthy lifestyle student youth: the experience of regional research, Theory and practice of physical culture, 4, 44-46 (2016)

15. V.A. Khlebnikov, Physical culture as a component of a healthy lifestyle, Modern social and humanitarian research: theoretical, methodological and applied aspects: a collection of scientific papers based on the materials of the International scientific and practical conference, 2, 135-139 (2019)

16. S.I. Belykh, Strategies for improving students' physical education, Theory and practice of physical culture, 10, 97 (2015)

17. A.E. Bolotin, Substantive and organizational aspects of the formation of healthy lifestyle skills among university students, Theory and practice of physical culture, $\mathbf{6}$, $18-20$ (2016) 